\title{
Epilogue: \\ Creative Persona and \\ the Problem of Authenticity
}

\author{
Edward M. Bruner
}

The theme of this volume, that the creative persona has the power of transformation and transcendence and can change a culture, is both obvious and subtle. We know that there have always been charismatic prophets, political leaders, and intellectual giants who move peoples and nations, and who change the scholarly directions of an historical era. One thinks of Newton and Einstein, Alexander the Great and Napoleon, Jesus and Mohammed, Joyce and Proust. Such exceptional individuals even have a place in superorganic theories of culture. But in the theory held, for the most part, by the contributors to this volume, even little people in the routine and the everyday construct their lives as they live their lives. Changes initiated by persons of power or by elite groups do have a higher probability of being more widely accepted by the larger society, but change occurs among all social classes and segments. Transformation and transcendence are especially marked in cultural performances, in what Victor Turner has called putting experience into circulation, for it is in performance that a society is most articulate and powerful in giving expression to its key cultural symbols, paradigms, and narratives.

Look at it this way:

If we believe that culture is heavy, ponderous and static, If it's a slowly changing beast, 
If there is nothing new under the sun,

If culture is a burden, even oppressive, a weight to bear,

THEN:

It takes a giant to move the world, even a little.

BUT:

If we see culture as always in production, as constituted and reconstituted in every act,

If we agree with the American pragmatists, with Dilthey, and with the hermeneutic tradition that meaning is not prior to an event but is emergent in the event,

If we agree with the French poststructuralists that events do not simply trigger or release a preexisting meaning buried in the text, underlying surface manifestations, behind them or beneath them, and if we see meaning as uncontrollable, as radically symbolic,

If we see culture as alive, in constant movement,

If we agree that every cultural expression is different, however slightly, from the previous expression, if only because the context is different,

If we agree that the various domains of culture are not congruent and do not replicate one another, but rather that there is a dynamic tension between domains,

If we acknowledge that cultural codes, rules, and norms never encompass all of the situations in which individuals find themselves, so that improvisation is a cultural imperative,

If we believe that cultural transmission is not a mechanical replication or reproduction of the heavy heritage of the past,

If we believe all these things, and if we believe in an anthropology of experience, practice and performance,

THEN:

One does not have to be a Napoleon to change a culture.

The little guy has a chance.

It's not only easy to change culture, but we do it all the time.

And if this is so, then creative personas have a wide-open field.

She and he, can do anything-if not move the world then, at the very least, they can move themselves and their culture. What Shostak found for the !Kung is actually universal; 
"creative expression takes place almost anywhere, during any segment of the day."

That change is inherent in social life is not news. We have had enough critiques of static views of society over past decades to question the separation between homeostasis and transformation. Nevertheless, as Barbara Babcock and others suggest, we somehow feel compelled to "explain" change by reference to the gifted genius, the marginal individual, the charismatic prophet, or we evoke special features of the context, such as historical forces, unsettled times, or even the proverbial raiders from the north. It is as if the initial condition of man, or to borrow a term from computer terminology, the default setting, is one of no change, and every instance of change or innovation is an aberration from that comfortable initial state. The image that comes to mind is of society, somehow, settling down in an overstuffed easy chair, and so reluctant to depart from that idyllic condition that every movement becomes a special event demanding an explanation.

All creative activity, in this view, is attributed to some extraordinary person, time or place. Even Victor Turner, who did more than anyone to open up anthropology by focusing our attention on process and on reflexivity, privileged the liminal and the liminoid, at least in some of his writings $(1969,1974)$, to such an extent that creativity was relegated to the "extra" ordinary, which diminished the everyday. It is ironic that in his lifelong struggle against formalism and structuralism, Turner so stressed the exceptional-the social drama, the betwixt and between, and the marginal-that, in effect, he abandoned ordinary social life to Radcliffe-Brown. Society became a rather dull place regulated by jural rules and structural principles, a place from which one departed temporarily for a flourish of excitement, creativity, and change, only to return, transformed but exhausted, to a dronelike existence. Turner, of course, was well aware of this criticism and did change the emphasis in his later writings.

How frequently have we read ethnographic accounts in which change was attributed to extraordinary conditions, and particularly to situations of interaction between two or more cultures, to contact between peoples, revolutionary times, or to the coming of the white man, the missionaries, the traders, the settlers, or even the tourists. Yet, we well know that societies have long had to contend with other tribes, with religious proselytizers, with trade, migrations, and probably with strangers, as part of the very conditions of human existence. 
As Marjorie Shostak notes, creativity is not a rare occurrence to be placed in a special category without which cultures would stagnate, nor is primitive society necessarily slow to change. We do, certainly, have periods of conquest and empire as well as epochs of more rapid change, but this does not imply that the periods in between are characterized by an absence of innovation or by a condition of stasis.

The essays in this volume struggle with ways of describing innovation, creativity, and change. The aim is twofold: to see process as part of structure rather than to view the two as in opposition (Wagner 1975, Giddens 1979); and to see the context as part of the text, rather than to view one as penetrating as an outside force upon the domain of the other. What is so difficult about these efforts is that built into our Western metaphysics (Derrida 1974) is the notion of a privileged original, a pure tradition, which exists in some prior time, from which everything now is a contemporary degradation. This is what James Clifford (1986) calls the pastoral allegory including the search for origins, the ethnographic present, and the idea of the vanishing primitive taken as a disappearing object, as a trope. It is what I call the problem of authenticity.

The pastoral has been attacked on all fronts (Fabian 1983), an attack that the essays in this book powerfully reflect. But there is irony here. At the time that ethnography is changing, we have an increase in international mass tourism. Just when ethnographers have given up the quest for the exotic, authentic original-the source, hordes of tourists are demanding it, and getting it, all over the world as cultural performances are constructed to fulfill tourist expectations. Ethnographers want thick description; tourists, thin description. Ethnographers seek a processual historical world; tourists, the timeless, ethnographic present. Ethnographers demand complexity; tourists, ready accessibility.

I studied tourism with Barbara Kirshenblatt-Gimblett, and if there is one thing we learned, it is not to underestimate the power of the tourist quest for the authentic savage. Tourists are searching for "experience" and for their "origin" through the rural, the primitive, the childlike, the unpolluted, the pure, and the original. They are returning to the Garden. In the past, travel accounts (Pratt 1985) were the major genre through which Western peoples were exposed to the primitive world, but these days affluent Westerners take organized tours and explore that world on their own. Now, tourists can even choose exactly how much authenticity they want. Smadar Lavie tells 
of a fake Bedouin tourist village in the Sinai, but for those with less time or a more delicate disposition there is, just outside Jerusalem, a fifty-minute presentation at an ersatz Bedouin encampment. Tourists can find whatever degree of Bedouin-ness they want.

In a sense, ethnographers and tourists are in competition, for both go to foreign lands and return with representations of their experience. The ethnographic product is primarily written, but tourism differs in the fascinating respect that it translates experience into image and object, that is, into photographs and souvenirs. Writing, photos, and objects are equally "representations," but the key difference is that the ethnographic experience is primarily verbal, occurring through language (although it also contains images), whereas the tourist experience is primarily nonverbal and visual, expressed through images and objects (Fernandez 1986). In the Third World countries we visited-Indonesia, Kenya, and Egypt-tourists generally do not speak in a meaningful way with anyone except other tourists, tour guides, or with those locals who are part of the tourist industry. They relate to the local people by looking at them, photographing them, and by purchasing whatever objects, as well as slides and postcards, that are presented for sale. Objects, as material mementos, encapsulate the tourist experience and reduce it to size.

Aside from whatever economic exploitation may be involved-an issue which has been dealt with in the literature-there is a moral dimension that we may not yet have come to terms with. Balinese and Maasai and Bedouin are being transformed into signs of themselves, culturally specific ones to be sure, but, nevertheless, they are becoming objects, like the souvenirs they sell. From the tourist perspective, indigenous peoples come to stand for African-ness or primitiveness although, from the native perspective, the performances have cultural meaning. What should be the moral position of anthropologists on this issue?

Authenticity, then, has become problematic. Ethnographers are rejecting the quest for authenticity and are examining the ethnographic process (Clifford and Marcus 1986), a theme that has shaped these essays; tourists, however, are still seeking authenticity with a vengeance; and the peoples we study are now questioning their own authenticity. Indeed, the papers by Kirin Narayan and Lavie are essentially about authenticity. Is this guru genuine or a fraud? Swamiji not only tells his disciples how to distinguish between a real guru and a charlatan, but he mocks the Western fascination with India. During 
a moment of cultural self-doubt the Mzeina Bedouin, concerned about how to maintain their own tradition of hospitality given the influx of visitors and tourists, ask if they themselves are any longer real Bedouin! And in a curious turn so characteristic of this postmodern era, Smadar Lavie, half Yemenite and half Lithuanian, an Arab Jew, an Israeli studying at Berkeley, finds herself assuring the Bedouin that their traditions are still "alive and well."

For ethnographers, tourists, and indigenous peoples the question is not if authenticity is inherent in an object, as if it were a thing out there to be discovered or unearthed, but rather, how is authenticity constructed? What is the process by which an ethnography, a tourist performance, or any item of culture or practice achieves an aura of being authentic? What are the processes of production of authenticity? Just as ethnicity is a struggle (Fischer 1986), authenticity, too, is something sought, fought over, and reinvented.

As Renato Rosaldo shows, the unpredictability, variability, ambiguity, and indeterminacy in culture provides the "social space within which creativity can flourish." People construct culture as they go along and as they respond to life's contingencies. No one denies the importance of rules and codes, but we will never understand how culture works, or how it changes, unless we take account of the human capacity for improvisation and creativity. Rather than ask what culture is, ask how culture is achieved, produced, and made believable.

Narayan's essay highlights the continuing dialectic between creativity and tradition, between person and persona, as Swamiji actively constructs his role as guru. He plays with his audience and comments on his culture. If there were no person but all persona, then we would have a fastidious performance but no change. If it were all person and no persona, then we would have social chaos. If, however, the person participates in the construction of a persona, if it is role making rather than role taking, then there is the potentiality for creativity.

Richard Schechner describes how dramatic narrative, ritual, and theater are so often explicitly violent and sexual, themes which are simultaneously the most serious and the most playful. Aggression and sex are the stuff of serious play, cross-culturally, in theater as varied as the Ramayana, Japanese noh, and sadomasochistic shows in New York. What is cruel and what is obscene capture the imagination, and Schechner suggests there is a human "need" for representations in play of these potentially destructive, and creative, impulses. The sheer 


\section{Epilogue}

amount of human creative energy that has gone into the play of aggressive and sexual themes is probably beyond calculation.

Shostak strikes a note of caution here. Her essay explores what creativity means to the !Kung, and shows how the !Kung artist must strike an egalitarian balance between creative expression and social expectation. The creative person in !Kung life must not claim selfimportance or superiority, but within these limits, creativity flourishes. The general point is that there are always cultural constraints, not only on improvisation itself but on the general acceptance of an innovation by others.

This book both questions the ethnographic process and takes a radical turn in how it deals with subject-object relations. Those we had previously called our "informants" have been rescued from anonymity. We are talking about Ceferino Suárez, Swamiji, Jimmy, Helen Cordero, Induan Hiling, Américo Paredes, and the others. They are not absent from the text. They are presented in our ethnographic texts as historically situated persons, with voices, names, and presence. It is hard to call them informants anymore or even by the trendy term "consultants." They emerge in these papers as full-fledged personalities, and our new way of dealing with them has changed us, as ethnographers. We, too, have become less anonymous, less the objective scientific recording machine.

Names are significant, in that by giving names we locate our informants contextually, acknowledge their history, and position them in a particular social setting. In the past, we constructed an anonymous informant, the generalized Hopi or the Bushman, which enabled us to assert our dominance in the relationship (Pratt 1985). To provide names is to demystify the ethnographic process and to expose its mechanisms of construction. To name an informant is to give up some measure of our own power, and paradoxically, to the extent that we yield control we are free to become more creative. Also, providing names unmasks the assumed homogeneity of primitive peoples, that never-never land where one informant was, more or less, like any other. Ethnographers have always had names; now that our informants do, the gap between subject and object is further reduced.

It is ironic that the "new" new ethnography which celebrates the informant also runs the risk of celebrating the ethnographer. Michel Foucault asks, "What is an author?" (1977). He might have been surprised by the answers provided by those experimental ethnogra- 
phies that deal with subject-object on the level of interpersonal relations more than on the level of discourse. The current critique of these ethnographies is that they are self-indulgent, too introspective, and even narcissistic. But as my colleague Alma Gottleib has remarked, the problem is to distinguish between narcissism and reflexivity. As we have paid increasing attention to the construction of the ethnographic text, we have put the ethnographer back into the text, and it may be that in some cases the ethnographer's role has become too prominent, or as James Fernandez writes, we may not have paid enough attention to voices on the ground. Of course, we must do so. The crucial point is to have both voices, multiple voices, in dialogic interplay.

I like it when the involvement, the stance, and even the commitment of the ethnographer are apparent in the text. The delight and the joy that Edith Turner evokes when she tells the story of the pilgrimage to the tomb of Bar Yohai clearly stem from the Turners' long-standing interest in ritual and pilgrimage, but also reflect the fact that the Turners are Catholic converts. Barbara Myerhoff shows that the ethnography takes shape through our own understanding and our own experience, and we, too, become the objects of our own inquiry. That Lavie is an Israeli with an Arabic-speaking Yemenite grandmother, who sees her own predicament reflected in the Bedouin, helps me to understand her account better. Narayan, the anthropologist/folklorist, describes herself as "a demure sari-wearing daughter of Nasik," whose grandmother is an orthodox Brahman. Her ethnographic project may be part of her personal effort to determine what is genuine and what is spurious in Indian and in Western tradition.

I even see similarities between the ethnographers and the informants they have selected, although I recognize this may be an outrageous presumption on my part. But Narayan is as droll as Swamiji. Don Handelman is as thoughtful and reflective as Henry Rupert. Anna Tsing is as innovative as Induan Hiling, Barbara Babcock as creative as Helen Cordero. José Limón is another Américo Paredes. Schechner is a parashaman. Fernandez, like Ceferino Suárez, is playful, poetic, and ironic. If I am correct in these perceived similarities between the ethnographers and their informants, it may be because both are engaged in what is essentially the same enterprise. Swamiji, Ceferino, and Helen Cordero, like Narayan, Fernandez, Babcock, and the others, are all storytellers, struggling to express themselves, to comment on their society and their times, and to establish their own position 


\section{Epilogue}

in the larger scheme of things. Ethnographers have always constructed their ethnographic texts, but now the ethnographers are entering the world they have constructed, living in that world, looking around, finding others to have conversations with, and reporting on the dialogue. Lavie's informant asks, "So who are the Bedouin and who are the guests?" I ask, "So who are the subjects and who are the objects?"

Ethnography is getting much more interesting than I, for one, had ever imagined.

The voices in these papers not only include those of the ethnographer and the informant but extend to the world system within which they are embedded-Cuba, the Camp David accords, the Anglo art market in the southwest of the United States, native texts saying "made in China," and to Sephardic pilgrims in an Israel dominated by an Ashkenazi political elite. These voices from afar have always been present in ethnographic encounters, but until recently we have not considered it worthwhile or appropriate to record them. The essay by Fernandez is especially sensitive to the dialogic in its attention to Ceferino's "particular voice" and its place among other voices from the village and beyond. Fernandez is also attentive to the "ambiguous interplay of forces coming into being and forces passing away," so that dialogic narration is seen as continually in construction and as moving with currents of history. Ceferino's voice is not just there, or once found, forever fixed; he constantly struggles to find his voice. It is fragile, ever changing. James Boon (1984) is correct; the world is a wayang, a Mardi Gras, a mélange, always in motion.

Handelman calls our attention to other voices that are absent from the text. Some individual informants have dealt with a series of ethnographers as well as with journalists, photographers, and assorted seekers of the exotic other. There is a history of their relationship to outsiders. Helen Cordero's grandfather was an informant to Adolph Bandelier, Edward Curtis, and Ruth Benedict; her mother was Esther Goldfrank's main informant; and Helen is working with Barbara Babcock. We have extended families and entire lineages of information givers! Handelman reports that Henry Rupert had had contact with six other ethnologists before him, and that Rupert was very aware that Handelman was one of a series. The point is that such informants not only have an active role in constructing their culture, they not only edit themselves to use Handelman's phrase, but they have an active role in constructing us and our discipline. One sees so clearly now that there are two active selves in the ethnographic process, them and 
us, both interpreting themselves as they are interpreting the other. We have long realized that all ethnographers approach the field with a prior agenda - there are no naive ethnographers-but neither are there naive informants.

Handelman points to the importance of discursive practices, to what we might call the political economy of the text, that is, the restraints imposed on our ethnography by the conventions of the discipline, by our career orientation, by our claim to "authorship" and originality. Consider, for example, a bibliography in comparison with a preface. We have paid attention to prefaces (Nelson 1976, Pratt 1986, Clifford 1986) and to the entry stories they contain. But what of the bibliography, to the claims of authority it makes? Prefaces appear at the beginning of the text, but they are usually written last; bibliographies appear at the end of the text, but they are probably written, or known, first. Or at least we know in advance the body of literature to which we shall refer. What a bibliography does is to locate the author within the wider anthropological community. A bibliographic citation is very much part of the text but is not just an objective reference; it is also a political statement that stakes the author's claim to a position within a particular scholarly tradition. But as Handelman notes, the voices of other ethnographers are allocated a very narrow space in the discourse.

These essays call attention to political issues, to questions of authority and the politics of creativity. The point is not creativity in opposition to politics but creativity in the service of politics. The theme runs through Babcock's paper. It is not just the association of corn and pottery and fertility, but it has to do with what is men's business and with women's business. The paradigm had been symbolic power for women and political power for men, but Helen Cordero is changing that. The narrative focus also emerges in Babcock's paper, where we see storytelling as reproduction and as a mechanism of power, as well as of meaning. The profoundly political question becomes the following: who has the right, by what means, to tell what stories? It will be interesting to follow these developments along the Rio Grande.

Anna Tsing, like Babcock, deals with creativity in expression and politics, and shows how women's work can revise a male-dominated tradition. What women do is to incorporate the dominant conventions at the same time as they invert them, resist them, and transform them. Change occurs more through an end run than a frontal attack. Tsing stresses improvisation and deals with the cutting edge of resistance, 


\section{Epilogue}

showing how a female activity can be a commentary on male shamanism and an expose of male practice. The crucial issue, again, is who has space in the discourse and the right to politically significant, expressive models. Tsing notes that women are disadvantaged "not so much by what was said but by who got to speak."

Voices again, active selves, and a balance between authoritative tradition and original knowledge.

Limón, too, deals with power, politics, and narrativity. He tells the story of Gregorio Cortez, based on events in 1901: a migrant journeys from the border, has a confrontation with the Anglos, and returns to reestablish links with his native community. It is a resistance narrative (Bruner 1986), one retold in the 1958 book by Américo Paredes, in the life story of Paredes as reconstructed by Chicano activists, in the paper by José Limón included here, and in the events of Limón's life as implied in the text. Cortez, Paredes, and Limón all sing the same corrido. But every time the story is told, it resonates with individual experiences of discrimination, which revitalize and personalize the narrative, and make it more vivid. What is remarkable in Limón's paper is how a folk ballad becomes an anthropological text, which in turn is transformed into a ballad again in a new historical era of activism in the 1960s, and in Limón's able hands, is retold as text in the 1980s for an audience of interpretive anthropologists. Which is the etic and which is the emic? Where is the difference here between subject and object? The distinction between "them" and "us" has dissolved; it appears that we are them and they are us.

An interesting question becomes, what happens to old stories? With each retelling in the present the original is transformed, for the past is never just recalled; it is always constructed. The original events of 1901 were changed by Paredes in 1958, modified by the Chicano movement, and again by Limón's current text. Old stories are like data entries in a computer spreadsheet. Each new entry changes the other totals in the spreadsheet, instantaneously, as all data and formulas in the spreadsheet are completely interactive. Computers have no consciousness, so the analogy is flawed, but the point is that old stories are never just stored in memory nor are they ever really recoverable, for they change with each telling. We can recover the words of the story but never the same context or the prior interpretation, if only because the world has changed and we are different. There are no authentic originals, only a process of authentication.

Edward Schieffelin's elegant essay on mediums in Papua New 
Guinea shows us how authenticity is constructed in Kaluli séance, or more generally, how people experience a ritual and how the performance becomes compelling, believable, and transformative. We see how the medium commits the participants to the construction of the performance, and how, while searching for clarification of the spirit's message, the people "create the meaning they discover." How could we ethnographers have ever described any performance, either ritual or narrative, without dealing with the audience as creative agents who engage in acts of interpretation? Schieffelin sets our priorities straight when he writes that it is the performance that accounts for the belief system rather than the other way around. Meaning is not in the text but is emergent in the performance. And Schieffelin, like Rosaldo, shows how the open spaces and indeterminacies in social life lead people to reach for meaning and thereby to construct themselves and their societies. This essay celebrates the revolutionary potential in ritual and demonstrates that change is inherent in structure.

Myerhoff's essay, probably her last, is poetic, personal, and profound. It communicates the excitement of a journey into the anthropology of experience, connects the inner and the outer worlds, and shows how culture is made "real and immediate to each person." We see that only in performance are we made the embodiment "of the stories we tell." Because the essay is incomplete, constructed by Edith Turner from notes, it reminds us that all ethnography is partial and incomplete, and the very incompleteness of text and life requires that we constantly strive for understanding. Authenticity is a struggle, not a given. Myerhoff demonstrates how individual persons become invaded by persona, how a private life partakes of a collective tale, and how a bridge is constructed between biography, culture, and history.

Edith Turner tells the story of the pilgrimage to the shrine of Meron in the northern Galilee in 1983, showing that just as Bar Yohai's legacy is renewed and refashioned in contemporary Israel, so the legacy of Barbara Myerhoff and Victor Turner, both of whom participated in that pilgrimage, reaches out "beyond their own deaths." Creative personas do outlive themselves and there is a diachronic chain of poetic selves.

It is appropriate that this volume be dedicated to the memory of Victor Turner, for we are writing about him. He is our subject matter, as these papers are about the creative persona, and he is the archetype 


\section{Epilogue}

of the creative spirit in anthropology. His power, whimsy, and spark inspired so many of us and encouraged us to actualize our own creative potential. There is a chain of poetic selves, from Victor Turner to us.

I conclude by paying tribute to creative personas, to:

a village poet in northern Spain

a Hindu guru

a !Kung musician

a Pueblo potter

a Meratus shaman

the Bedouin in the Sinai

a Washo healer

a Sephardic holy man in second-century Palestine

a Chicano scholar and activist

and to Victor Turner, the personification of the creative spirit.

And I pay tribute to us, to the creative persona in all of us.

\section{REFERENCES}

Boon, James A. 1984. "Folly, Bali, and Anthropology, or Satire across Cultures." In Edward M. Bruner, ed., Text, Play, and Story: The Construction and Reconstruction of Self and Society. 1983 Proceedings of the American Ethnological Society. Washington, D.C. Pp. 156-77.

Bruner, Edward M. 1986. "Ethnography as Narrative." In Victor W. Turner and Edward M. Bruner, eds., The Anthropology of Experience. Urbana: University of Illinois Press. Pp. 139-55.

Clifford, James. 1986. "On Ethnographic Allegory." In Clifford and Marcus, eds., 1986. Pp. 98-121.

Clifford, James, and George E. Marcus. 1986. Writing Culture: The Poetics and Politics of Ethnography. Berkeley: University of California Press.

Crick, Malcolm. 1985. " 'Tracing' the Anthropological Self: Quizzical Reflections on Field Work, Tourism, and the Ludic." Social Analysis 17:71-92.

Derrida, Jacques. 1974. Of Grammatology. Trans. Gayatri C. Spivak. Baltimore: Johns Hopkins University Press.

Fabian, Johannes. 1983. Time and the Other: How Anthropology Makes Its Object. New York: Columbia University Press.

Fernandez, James W. 1986. "The Argument of Images and the Experience of Returning to the Whole." In Victor W. Turner and Edward M. Bruner, eds., The Anthropology of Experience. Urbana: University of Illinois Press. Pp. 15987. 


\section{Edward M. Bruner}

Fischer, Michael M. J. 1986. "Ethnicity and the Post-Modern Arts of Memory." In Clifford and Marcus, eds., 1986. Pp. 194-233.

Foucault, Michel. 1977. "What Is an Author?" In Donald F. Bouchard, ed., Language, Counter-Memory, Practice: Selected Essays and Interviews by Michel Foucault. Ithaca: Cornell University Press.

Giddens, Anthony. 1979. Central Problems in Social Theory: Action, Structure and Contradiction in Social Analysis. Berkeley: University of California Press.

Kirshenblatt-Gimblett, Barbara, and Edward M. Bruner. n.d. "Tourism: Performing Ethnographic Tropes."

Nelson, Cary. 1976. "Reading Criticism." PMLA 91: 801-15.

Pratt, Mary Louise. 1985. "Scratches on the Face of the Country; or, What Mr. Barrow Saw in the Land of the Bushmen." Critical Inquiry 12: 119-43.

. 1986. "Fieldwork in Common Places." In Clifford and Marcus, eds., 1986. Pp. 27-50.

Turner, Victor. 1969. The Ritual Process. Chicago: Aldine. 1974. Dramas, Fields, and Metaphors. Ithaca: Cornell University Press.

Wagner, Roy. 1975. The Invention of Culture. Englewood Cliffs, N.J.: PrenticeHall. 